Państwo i Społeczeństwo

2015 (XV) nr 3

\author{
Małgorzata Salasa, Anna Goździalska
}

Krakowska Akademia im. A. Frycza Modrzewskiego,

Wydział Zdrowia i Nauk Medycznych

\title{
OCENA STANU WIEDZY DOTYCZACCEJ ZACHOROWALNOŚCI NA OSTRE ZAPALENIE WĄTROBY TYPU B I C WŚRÓD PERSONELU MEDYCZNEGO
}

\author{
adres korespondencyjny: \\ Anna Goździalska, Krakowska Akademia im. Andrzeja Frycza Modrzewskiego, Wydział Zdrowia \\ i Nauk Medycznych, ul. Gustawa Herlinga-Grudzińskiego 1, 30-705 Kraków \\ e-mail: anna.gozdzialska@gmail.com
}

\section{Streszczenie}

Wprowadzenie: Zakażenia szpitalne w dużej mierze dotyczą samych pracowników służby zdrowia. Zwiększony zakres usług medycznych, w tym dużo większa liczba zabiegów operacyjnych, ma wpływ na wzrost zakażeń wirusami zapalenia wątroby typu B (HBV) i C (HCV) w tej grupie zawodowej. Głównymi czynnikami wystąpienia zakażeń szpitalnych wśród osób zatrudnionych w sektorze opieki zdrowotnej, są choroby będące wynikiem narażenia na czynniki biologiczne w trakcie wykonywania czynności służbowych. Według WHO, co roku na świecie 3 miliony pracowników medycznych jest narażonych na przezskórny kontakt z krwiopochodnymi patogenami. Celem badań była ocena wiedzy dotycząca zachorowalności na ostre zapalenie wątroby typu B i C wśród personelu medycznego.

Wyniki i wnioski: Analiza poziomu wiedzy personelu medycznego na temat zachorowalności na WZW typu B i C wskazuje na właściwe zachowania w przypadku kontaktu z materiałem zakaźnym w placówkach służby zdrowia.

Słowa kluczowe: zakażenia poekspozycyjne, zakłucia, pielęgniarki, lekarze 


\section{Wprowadzenie}

Współcześnie bardzo szybko wzrosło znaczenie schorzeń powodowanych przez wirusy hepatotropowe B i C, głównie z powodu ich późnych następstw (przewlekłe zapalenie wątroby, marskość i rak pierwotny tego narządu). Szacuje się, że na świecie około 2 mld ludzi miało kontakt z HBV a ponad $350 \mathrm{mln}$ choruje na przewlekłe WZW B, z czego około $15-25 \%$ umrze z powodu niekorzystnego przebiegu i skutków tego zakażenia - marskości wątroby lub pierwotnego raka tego narządu. Jak wynika $\mathrm{z}$ analiz, rocznie odnotowuje się około 600 tys. zgonów z powodu zakażenia HBV [1]. Polska zaliczana jest do krajów o niskiej częstotliwości występowania zakażenia HBV, gdyż przewlekła obecność HBsAg stwierdzana jest u $1,4 \%$ populacji [2].

Szacowane jest ponadto, że każdego roku przybywa blisko 3-4 mln zakażonych. Eksperci Światowej Organizacji Zdrowia przewidują, że w ciągu 20-30 lat podwoi się (a nie wyklucza się, że nawet potroi) liczba zgonów z powodu $\mathrm{HCV}$, dlatego też WHO określiła zakażenie wirusem $\mathrm{C}$ zapalenia wątroby jako viral time bomb [3].

Według danych Państwowego Zakładu Higieny i Instytutu Hematologii i Transfuzjologii, uznawanych przez WHO, w Polsce zakażenie HCV dotyczy około $1,4 \%$ populacji [4], a liczba nowo wykrywanych infekcji zwiększa się. Rzeczywista liczba świeżych zakażeń nie jest znana, gdyż wywołane przez HCV schorzenie od początku przebiega najczęściej skrycie. Dlatego też WZW typu C zwykle jest wykrywane przypadkowo lub w późnej objawowej (marskość wątroby/pierwotny rak wątroby) fazie zakażenia.

Czynnikiem etiologicznym WZW B jest HBV należący do rodziny $\mathrm{He}$ padnaviridae [3,4]. Wrotami zakażenia jest naruszenie ciągłości tkanek skóry lub błony śluzowej. Do zakażenia wystarczy wprowadzenie $0,00004 \mathrm{ml}$ zakażonej krwi [5].

Wirusowe zapalenie wątroby typu $\mathrm{C}$ jest skutkiem zakażenia wirusem HCV. Wirus Zapalenia Wątroby typu C (Hepatitis C Virus, HCV) wywołuje u człowieka ostre i przewlekłe choroby wątroby. Jest on zaliczany do rodziny Flaviviridae [6]. Objawy WZW C są podobne do objawów WZW B, ale nie są tak burzliwe: często nie ma żółtaczki, za to pojawia się świąd skóry.

Istotą ostrego zapalenia wątroby jest uszkodzenie wątroby, co znajduje odzwierciedlenie w analizach laboratoryjnych, takich jak wzrost stężenia bilirubiny całkowitej w surowicy krwi, zwiększenie aktywności tzw. enzymów wątrobowych: AlAT i AspAT w surowicy, wzrost aktywności dwóch innych enzymów w surowicy: fosfatazy alkalicznej (FA) i GGTP, który świadczy o tzw. cholestazie, oznaczenie znaczników serologicznych ostrego zakażenia HBV (HbsAg + HbeAg + HbcIgM +++), HBV-DNA PCR czyli wykrycie DNA wirusa WZW typu B we krwi metodą PCR [7]. 
WZW C rozpoznaje się na podstawie takich badań laboratoryjnych, jak: poziom stężenia bilirubiny całkowitej w surowicy, wzrost aktywności AlAT i AspAT w surowicy krwi, oznaczenia w surowicy obecności przeciwciał anty-HCV oraz oznaczenia obecności HCV-RNA metodą PCR [7,8].

Za ekspozycję (narażenie), która stwarza ryzyko zakażenia, uważa się zakłucie lub zranienie zdrowej skóry skażonym, ostrym przedmiotem (igłą, skalpelem, lancetem, wiertłem itp.) lub kontakt błon śluzowych albo uszkodzonej skóry (pęknięcia, otarcia, zmiany zapalne, rany, oparzenia, sączące zmiany alergiczne) z potencjalnie zakaźną krwią, tkankami lub płynami ustrojowymi pacjenta [7].

Ekspozycja zawodowa to kontakt z materiałem potencjalnie zakaźnym, do którego doszło w trakcie wykonywania pracy zawodowej [9]. Za grupę zawodową najbardziej narażoną na kontakt z potencjalnie zakaźnym materiałem uznaje się pracowników medycznych [10].

Najbardziej narażoną grupę pracowników medycznych stanowią pracownicy wykonujący zadania związane z dużym ryzykiem przerwania ciągłości tkanek, takich jak: udział w operacjach i wykonywanie czynności związanych z opatrywaniem ran, wykonywanie iniekcji, intubacji, badań endoskopowych, odbieranie porodów, prace przy utylizacji odpadów medycznych, i tym samym zwiększonym ryzykiem zakażenia się wirusami przenoszonymi drogą krwiopochodną [11]. Według danych epidemiologicznych do zawodów medycznych, które cechuje największe ryzyko zakłuć ostrym narzędziem w placówkach służby zdrowia, należą pielęgniarki i lekarze [12].

Najistotniejszym materiałem biologicznym - z punktu widzenia ryzyka transmisji czynnika zakaźnego w warunkach pracy służby zdrowia - jest krew, zaś najczęstszym mechanizmem transmisji zakażeń przenoszonych drogą krwi jest niezamierzone skaleczenie ostrym sprzętem medycznym skażonym krwią pacjenta - źródłem zakażenia. Poza krwią zagrożenie stanowią nasienie i wydzielina pochwy oraz inne płyny ustrojowe, takie jak: płyn mózgowo-rdzeniowy, stawowy, opłucny, otrzewnowy, osierdziowy, owodniowy, a także tkanki i narządy zakażonego chorego $[13,14]$. Na skutek ekspozycji na krew i płyny ustrojowe może dojść do zakażenia HBV, HCV, HIV - jako najbardziej niebezpiecznych i powszechnych zakażeń krwiopochodnych.

Z raportu Światowej Organizacji Zdrowia z 2003 r. wynika, że 37,6\% WZW B, 39\% WZW typu C oraz 4,4 \% zakażeń HIV rozpoznawanych wśród personelu medycznego na świecie jest spowodowanych zakłuciami igłą. Przekłada się to na około 65 tys. zakażeń HBV, 16,4 tys. zakażeń HCV i tysiąc zakażeń HIV rocznie. Średnia liczba zakłuć/pracownika/rok wynosi w Ameryce Północnej 0,18 , a w Europie - 0,64. W szpitalach amerykańskich co roku dochodzi do około 384 tys. tego typu incydentów, co przekłada się na ponad tysiąc skaleczeń dziennie, w szpitalach brytyjskich - do 100 tys., w niemieckich - do 500 tys. Szacunkowych danych pochodzących z polskich szpitali brakuje. W przeciętnym 
europejskim szpitalu dochodzi do 12-30 zakłuć na 100 łóżek, przy czym 60-80\% tych incydentów nie jest zgłaszanych. Najczęściej kaleczącym narzędziem jest igła ze światłem, następnie igła chirurgiczna. Do największej liczby zakłuć dochodzi podczas używania narzędzi medycznych, rzadziej po ich użyciu, ale przed utylizacją [15].

W Polsce niewiele jest opracowań z zakresu epidemiologii zakłuć ostrym sprzętem medycznym, a istniejące opierają się na danych dotyczących jednej grupy zawodowej czy pochodzących z jednej placówki lub jednego regionu. Ponadto, znaczna część opracowań opiera się jedynie na analizie zgłoszonych przypadków ekspozycji zawodowych, które stanowią znikomy procent rzeczywistej liczby tego rodzaju ekspozycji. Nawet jednak te niekompletne dane dowodzą, że problem zakłuć wśród pracowników służby zdrowia w Polsce istnieje [15].

Jak wynika z badań przeprowadzonych w 2004 roku przez Wrocławską Akademię Medyczną, w Polsce, co miesiąc dochodzi do zakłucia jednego na dziesięciu pracowników opieki zdrowotnej. Szacunki wskazują jednak, że niezgłaszanych nigdzie przypadków jest dużo więcej, nawet o 100\%. Podaje się, że około $10 \%$ personelu medycznego rani się narzędziami pracy, $6 \%$ ma kontakt z płynami ustrojowymi chorego przez uszkodzą skórę, a 4\% przez śluzówki [16].

Ogólne zasady postępowania po ekspozycji pracowników służby zdrowia na HBV, HCV:

- po ekspozycji niezwłoczne umycie zranionej/zanieczyszczonej skóry wodą z mydłem,

- nie należy używać środków dezynfekcyjnych na bazie alkoholu,

- jeżeli zanieczyszczone są oczy, należy przepłukać je dokładnie wodą lub roztworem soli fizjologicznej (przy otwartych powiekach),

- śluzówki jamy ustnej i nosa należy przepłukać kilkakrotnie wodą,

- nie należy wyciskać rany, nie wolno tamować krwawienia,

- jak najszybciej zgłosić ekspozycję wyznaczonemu lekarzowi,

- fakt wystąpienia ekspozycji na zakażenie należy zgłosić przełożonemu lub lekarzowi dyżurnemu,

- wystąpienie zdarzenia należy odnotować w Rejestrze ekspozycji zawodowych na zakażenie HIV, HBV, HCV,

- osoba eksponowana wypełnia Indywidualną kartę ekspozycji zawodowej na zakażenie HIV, HBV, HCV,

- osobę eksponowaną kieruje się do lekarza zakładowego, który wdraża postępowanie profilaktyczne i prowadzi jej obserwację przez 12 miesięcy,

- należy ocenić ryzyko zakażenia na podstawie: rodzaju ekspozycji (zranienie skóry igłą lub innym skażonym przedmiotem, zabrudzenie błon śluzowych lub uszkodzonej skóry, ugryzienie powodujące krwawienie) oraz rodzaju potencjalnie zakaźnego materiału (krew, inny płyn ustrojowy lub tkanki, skoncentrowane cząsteczki wirusa), 
- jeśli ekspozycja związana była z ryzykiem zakażenia, należy określić, czy pacjent, z którego krwią lub innym płynem ustrojowym miał kontakt pracownik, jest zakażony, opierając się na: danych klinicznych i epidemiologicznych, wynikach badań na obecność HBsAg, anty-HCV, anty-HIV,

- przeprowadzić badanie pracownika narażonego na zakażenie; ocenić stan uodpornienia przeciwko HBV, zebrać wywiad dotyczący aktualnych chorób, przyjmowanych leków, ciąży i karmienia piersią,

- jeżeli istnieje ryzyko zakażenia po ekspozycji rozpocząć odpowiednią profilaktykę,

- pobierając krew od osoby będącej potencjalnym źródłem zakażenia należy pamiętać o uzyskaniu zgody na przeprowadzenie badań na oznaczenie przeciwciał anty-HIV, anty-HCV i HBsAg [7,9].

Wszyscy pracownicy (zarówno zatrudnieni w ramach pełnego, jak i części etatu oraz w ramach kontraktu) narażeni w trakcie pracy na ekspozycję na materiał potencjalnie zakaźny powinni uczestniczyć w szkoleniu dotyczącym prewencji przypadkowych ekspozycji. Szkolenie na temat prewencji przypadkowych ekspozycji na materiał potencjalnie zakaźny powinno mieć miejsce przed rozpoczęciem pracy w narażeniu na czynności sprzyjające takim zdarzeniom i później powtarzane przynajmniej raz w roku.

Osoby wykonujące zawód medyczny narażone na zakażenie wirusem HBV podlegają obowiązkowemu szczepieniu przeciwko WZW typu B. Fakt przebycia cyklu szczepień powinien być udokumentowany, a informacja ta powinna znaleźć się w dokumentacji indywidualnej pracownika.

Higiena rąk stanowi podstawowy środek ograniczający rozprzestrzenianie się zakażeń. Jest to prosta czynność, ale brak konsekwentnego jej przestrzegania stanowi ogólnoświatowy problem w sektorze opieki zdrowotnej [17]. W placówkach medycznych najważniejszym wektorem transmisji drobnoustrojów są ręce pracowników, przede wszystkim lekarzy i pielęgniarek. WHO uznaje higienę rąk za podstawowy element zapobiegania zakażeniom szpitalnym, jednak często $\mathrm{w}$ praktyce klinicznej przestrzeganie tej zasady jest niewielkie (50\%) [18]. Szacuje się, że przyczyną około $20-40 \%$ zakażeń są drobnoustroje przenoszone przez ręce pracowników opieki zdrowotnej [8]. Mimo licznych szkoleń brakuje u pracowników medycznych nawyków mycia i odkażania rąk bezpośrednio po każdym kontakcie z pacjentem lub z potencjalnie zakażonym sprzętem, aparaturą i materiałami biologicznymi. Nie przestrzega się także podstawowych zasad higieny osobistej [19].

\section{Cel pracy}

Nadrzędnym celem przeprowadzonych badań jest ocena poziomu wiedzy dotycząca zachorowalności na ostre zapalenie wątroby typu B i C wśród personelu medycznego: pielęgniarek i lekarzy. 


\section{Material i metody}

Badania przeprowadzono metodą sondażu z wykorzystaniem techniki ankietowej. Ankieta została przeprowadzona anonimowo, dane są poufne, odpowiedzi uzyskano w formie pisemnej. Kwestionariusz ankiety składał się z 25 pytań zamkniętych, pierwsze pytania zawierały dane osobowe personelu medycznego: wiek, miejsce pracy, staż pracy, wykształcenie. W dalszej części pytania dotyczyły ogólnych wiadomości na temat postępowania w przypadku ekspozycji na materiał zakaźny. Ankietę przedstawiono Komisji Bioetycznej Krakowskiej Akademii, która wyraziła pozytywną opinię odnośnie planowanych badań (nr KBKA 17/O/2014). Badania przeprowadzono za zgodą prezesa Zarządu Centrum Medycznego Ujastek. W czasie zbierania danych do badań własnych przestrzegano ustawy o ochronie danych osobowych. Badania przeprowadzono od stycznia do marca 2015 roku w Centrum Medycznym Ujastek w Krakowie.

Uzyskane wyniki poddano analizie statystycznej przeprowadzonej w programie Analysis ToolPak. Poziom istotności, mierzony był testem Pearsona, przy użyciu współczynnika korelacji dla danych ciągłych. Poziom istotności powyżej $0,9(r>0,9)$ wskazuje na istnienie korelacji między ocenianymi cechami.

\section{Wyniki}

W badaniach uczestniczył zarówno personel pielęgniarski, jak i lekarski. Zdecydowaną większość personelu medycznego stanowiły kobiety (98\% pielęgniarek i $72 \%$ lekarzy). Zdecydowana większość ankietowanych posiadała ponad 20-letni staż pracy ( $48 \%$ pielęgniarek, $60 \%$ lekarzy). Najmniej (6\% pielęgniarek i $4 \%$ lekarzy) stanowiły kobiety ze stażem pracy od 1-5 lat. Badane pielęgniarki prezentowały różny poziom wykształcenia: $60 \%$ miało wykształcenie średnie, pozostałe badane kobiety - wykształcenie wyższe (licencjackie lub magisterskie).

Badaniem objęto grupę 50 osób z personelu pielęgniarskiego (98\% pielęgniarek i 2\% pielęgniarzy) i 50 lekarzy (wśród których decydowaną większość stanowiły kobiety $-72 \%$, natomiast mężczyźni - 28\%), ze stażem pracy od 1 do $>20$ lat $\mathrm{w}$ zawodzie. Przed przystąpieniem do badań respondenci zostali dokładnie poinformowani o sposobie wypełnienia i celu kwestionariusza ankiety.

Biorąc pod uwagę staż pracy ankietowanych pielęgniarek, zdecydowaną większość stanowiły pielęgniarki powyżej 20 lat pracy (48\%), najmniej liczną grupę stanowiły pielęgniarki ze stażem pracy $1-5$ lat (6\%). W przypadku grupy ankietowanych lekarzy, zdecydowaną większość stanowili lekarze ze stażem pracy powyżej 20 lat $(60 \%)$, najmniej liczną grupę stanowili lekarze pracujący $1-5$ lat (4\%).

Ze względu na wykształcenie personelu pielęgniarskiego, zdecydowaną większość stanowiły pielęgniarki z wykształceniem średnim (aż 60\%), najmniej ankietowanych było $\mathrm{z}$ wykształceniem wyższym (12\%). 
Z przeprowadzonych badań wynika, że u większości ankietowanych pielęgniarek (z wykształceniem średnim 53,3\%, licencjatem 57,2\%, wyższym 66,6\%) nie doszło do zakłucia się igłą, która miała kontakt z krwią. Pielęgniarki z wykształceniem średnim $(46,7 \%)$ potwierdziło zakłucie igłą, która miała kontakt z krwią, z licencjatem (42,8\%), z wykształceniem wyższym tylko 33,4\%. Analiza statystyczna wykazała bardzo silną dodatnią zależność, $(\mathrm{r}=1)$ między wykształceniem a prawidłowym postępowaniem w pracy pielęgniarskiej. Powyższe dane przedstawia Tabela 1.

Jak wynika z przeprowadzonych badań lekarze ze stażem pracy od 10-15 lat częściej mieli kontakt $\mathrm{z}$ zakłuciem igłą, która miała kontakt $\mathrm{z}$ krwią $(75 \%)$, ze stażem pracy 15-20 lat (54,5\%), powyżej 20 lat do zakłucia doszło u (40\%) lekarzy. Powyższe dane przedstawia Tabela 2.

Tabela 1. Incydent zakłucia się igłą podczas pracy wśród pielęgniarek

\begin{tabular}{|c|c|c|c|c|c|c|}
\hline \multirow{4}{*}{$\begin{array}{l}\text { Odpowiedzi } \\
\text { pielęgniarek }\end{array}$} & \multicolumn{6}{|c|}{$\begin{array}{l}\text { Czy podczas pracy zdarzyło się Panu/Pani zakłuć igłą, } \\
\text { która miała kontakt z krwią? }\end{array}$} \\
\hline & \multicolumn{6}{|c|}{ WYKSZTAŁCENIE PIELĘGNIAREK } \\
\hline & \multicolumn{2}{|c|}{ ŚREDNIE } & \multicolumn{2}{|c|}{ LICENCJAT } & \multicolumn{2}{|c|}{ WYŻSZE } \\
\hline & $\mathrm{n}=30$ & $100 \%$ & $\mathrm{n}=14$ & $100 \%$ & $\mathrm{n}=6$ & $100 \%$ \\
\hline TAK & 14 & $46,7 \%$ & 6 & $42,8 \%$ & 2 & $33,4 \%$ \\
\hline NIE & 16 & $53,3 \%$ & 8 & $57,2 \%$ & 4 & $66,6 \%$ \\
\hline
\end{tabular}

Tabela 2. Incydent zakłucia się igłą podczas pracy wśród ankietowanych lekarzy

\begin{tabular}{|c|c|c|c|c|c|c|c|c|c|c|}
\hline \multirow{4}{*}{$\begin{array}{l}\text { Odpowiedzi } \\
\text { lekarzy }\end{array}$} & \multicolumn{10}{|c|}{$\begin{array}{c}\text { Czy podczas pracy zdarzyło się Panu/Pani zakłuć igłą, } \\
\text { która miała kontakt z krwią? }\end{array}$} \\
\hline & \multicolumn{10}{|c|}{ STAŻ PRACY ANKIETOWANYCH LEKARZY } \\
\hline & \multicolumn{2}{|c|}{$1-5$ lat } & \multicolumn{2}{|c|}{ 5-10 lat } & \multicolumn{2}{|c|}{$10-15$ lat } & \multicolumn{2}{|c|}{ 15-20 lat } & \multicolumn{2}{|c|}{$>20$ lat } \\
\hline & $\mathrm{n}=2$ & $100 \%$ & $\mathrm{n}=3$ & $100 \%$ & $\mathrm{n}=4$ & $100 \%$ & $\mathrm{n}=11$ & $100 \%$ & $\mathrm{n}=30$ & $100 \%$ \\
\hline TAK & 1 & $50 \%$ & 1 & $33,3 \%$ & 3 & $75 \%$ & 6 & $54,5 \%$ & 12 & $40 \%$ \\
\hline NIE & 1 & $50 \%$ & 2 & $66,7 \%$ & 1 & $25 \%$ & 5 & $45,5 \%$ & 18 & $60 \%$ \\
\hline
\end{tabular}


W badaniu wszystkie ankietowane pielęgniarki (100\%) stwierdziły, że w przypadku zakłucia się należy wykonać badanie w kierunku HCV. Pielęgniarki z większym stażem pracy (15-20 lat) zgodnie stwierdziły, że po zakłuciu należy wykonać również badania na HIV (84\%) i HBV (100\%). Pielęgniarki ze stażem pracy powyżej 20 lat odpowiedziały, że należy również wykonać badanie HIV $(95,9 \%)$ i HBV(100\%). Pielęgniarki z mniejszym stażem nie podały konieczności wykonania badań HIV i HBV. Analiza statystyczna wykazała bardzo dużą dodatnią zależność $(r>0,99)$ posiadanej wiedzy w stosunku do stażu pracy.

W badaniu wszyscy ankietowani lekarze $(100 \%)$ bez względu na staż pracy zgodnie stwierdzili, że w przypadku zakłucia należy pobrać badania w kierunku HCV i HBV. Niestety nie wszyscy lekarze ze stażem pracy 1-10 lat (66\%) pamiętają, że w przypadku ekspozycji należy pobrać badania w kierunku HIV. Analiza statystyczna wykazała bardzo dużą dodatnią zależność $(r>0,99)$ posiadanej wiedzy w stosunku do stażu pracy lekarzy.

Zdecydowana większość pielęgniarek $(71,4 \%)$ bez względu na wykształcenie $\mathrm{w}$ przypadku zakłucia się niesterylnym narzędziem umyłaby ranę wodą z mydłem. W przypadku zakłucia się pielęgniarki wymieniły również takie czynności postępowania jak: wytarcie rany ręcznikiem papierowym, $(33,3 \% \mathrm{z}$ wyższym wykształceniem) czy wyssanie krwi z rany $(16,7 \%$ z wyższym wykształceniem). Analiza statystyczna wykazała słabą dodatnią zależność $(\mathrm{r}=0,2)$ między wykształceniem a deklarowanym postępowaniem w przypadku zakłucia $\mathrm{w}$ grupie badanych pielęgniarek.

W badaniach zdecydowana większość lekarzy zgodnie odpowiedziała, że po zakłuciu przede wszystkim należy umyć ranę wodą z mydłem (5-10 lat pracy $-66,7 \%, 10-15$ lat $-75 \%$ ). Duży procent lekarzy (ze stażem 5-10 lat pracy $33,3 \%$, a powyżej 20 lat - 40\%) odpowiedział, że w przypadku zakłucia zdezynfekowaliby ranę octeniseptem. Analiza statystyczna wykazała umiarkowaną dodatnią zależność $(r=0,49)$ między stażem pracy a deklarowanym postępowaniem w przypadku zakłucia.

Zdecydowana większość pielęgniarek stwierdziła, że stosuje rękawiczki w każdej czynności przy pacjencie (pielęgniarki z wykształceniem średnim - 60\%, z licencjatem 78\%, z wykształceniem wyższym - 66,7\%), Niestety nie wszystkie pielęgniarki stosują rękawiczki przy pobieraniu krwi, czy przy zmianie opatrunku (takiej odpowiedzi udzieliło 43\% pielęgniarek z wykształceniem średnim). Analiza statystyczna wykazała bardzo silną zależność $(r=0,9)$ między wykształceniem a stosowaniem środków ochrony osobistej - rękawiczek.

Jak wynika z badań, wszyscy ankietowani lekarze (100\%) zakładali rękawiczki przy zmianie opatrunku.

Z przeprowadzonych badań wynika, że wszystkie ankietowane pielęgniarki myły ręce po każdym kontakcie z pacjentem (pielęgniarki ze stażem pracy $>20$ lat aż 95,9\%). Spośród pielęgniarek ze stażem pracy powyżej 15 lat pracy $9 \%$ nie myło rąk po wykonaniu iniekcji. Analiza statystyczna wykazała bardzo silną zależność $(\mathrm{r}=0,9)$ między stażem pracy a myciem rąk w grupie pielęgniarek. 
Z przeprowadzonych badań wynika, że wszyscy lekarze (100\%) po kontakcie z pacjentem myli ręce. $10 \%$ lekarzy ze stażem pracy powyżej 15 lat pracy nie zawsze myło ręce po wykonaniu iniekcji. Analiza statystyczna wykazała bardzo silną zależność $(\mathrm{r}=0,9)$ między stażem pracy a myciem rąk w grupie lekarzy.

Według większości ankietowanych pielęgniarek w miejscu pracy są wywieszone procedury na wypadek ekspozycji HBV, HCV (średnie 93,3\%, wyższe $100 \%)$. Analiza statystyczna wykazała umiarkowaną zależność $(\mathrm{r}=0,4)$ między wykształceniem a świadomością występowania dostępnych procedur. Większość ankietowanych lekarzy również twierdzi, że w miejscu pracy są wywieszone procedury w przypadku ekspozycji HBV i HCV (5 lat pracy - 100\%, powyżej 20 lat pracy $-83,3 \%$ ).

Zdecydowana większość pielęgniarek (wykształcenie średnie 90\%, licencjat $92 \%$, wyższe $83 \%$ ) wiedziała, gdzie znajduje się dokument z zaleceniami po ekspozycji na materiał zakaźny. Analiza statystyczna wykazała umiarkowaną zależność $(\mathrm{r}=0,54)$ między wykształceniem a posiadaną wiedzą.

Z badań wynika, że zdecydowana większość lekarzy wiedziała, gdzie znajduje się dokument z zaleceniami po ekspozycji na materiał zakaźny (5-10 lat pracy $100 \%$, powyżej 20 lat pracy - 96,7\%) Analiza statystyczna wykazała umiarkowaną zależność $(\mathrm{r}=0,58)$ między wykształceniem a posiadaną wiedzą.

Wszystkie ankietowane pielęgniarki $(100 \%) \mathrm{w}$ przypadku wystąpienia ekspozycji poinformowałyby przede wszystkim przełożonego, a następnie szefa dyżuru. Mały procent pielęgniarek (5-10 lat pracy 25\%) poinformowałby pielęgniarkę epidemiologiczną w przypadku wystąpienia ekspozycji. Analiza statystyczna wykazała silną dodatnią zależność $(\mathrm{r}=0,9)$ między stażem pracy a wiedzą, kogo należy niezwłocznie poinformować, w przypadku ekspozycji.

Jak wynika z badań, wszyscy ankietowani lekarze w sytuacji ekspozycji na materiał zakaźny, zgłosiliby to zdarzenie przede wszystkim przełożonemu $(100 \%$ ankietowanych) a następnie szefowi dyżuru. Aż 50\% lekarzy ze stażem pracy do 5 lat nie wiedziało, kogo powiadomić w sytuacji dojścia do ekspozycji. Analiza statystyczna wykazała dużą dodatnią zależność $(\mathrm{r}=0,9)$ między stażem pracy a wiedzą na temat zgłoszenia zdarzenia ekspozycji.

Spośród badanych, nie miało oznaczanego poziomu przeciwciał anty HBS między $57,1 \%$ a $75 \%$ pielęgniarek, w tym najwięcej ankietowanych $(75 \%)$ ze stażem pracy 5-10 lat. Niski odsetek pielęgniarek - między $25 \%$ a $42,9 \%$, w zależności od stażu pracy - miało raz na rok badany poziom przeciwciał anty HBS. Powyższe dane przedstawia Tabela 3.

Zdecydowana większość lekarzy stwierdziła, że poziom przeciwciał anty HBS nie był kontrolowany, (15-20 lat pracy 63,6\%, powyżej 20 lat - 76,6\%). Niski odsetek lekarzy miał sprawdzany poziom przeciwciał anty HBS raz na rok (powyżej 20 lat - 23,3\%). Analiza statystyczna wykazała silną zależność $(\mathrm{r}=0,8)$ między stażem pracy a brakiem wykonywania oznaczeń poziomu anty Hbs. Powyższe dane przedstawia Tabela 4. 
Tabela 3. Kontrola poziomu przeciwciał anty-HBS wśród pielęgniarek

\begin{tabular}{|c|c|c|c|c|c|c|c|c|c|c|}
\hline \multirow{4}{*}{$\begin{array}{l}\text { Odpowiedzi } \\
\text { pielęgniarek }\end{array}$} & \multicolumn{10}{|c|}{ Jak często sprawdzany jest poziom przeciwciał anty-HBS? } \\
\hline & \multicolumn{10}{|c|}{ STAŻ PRACY ANKIETOWANYCH PIELĘGNIAREK } \\
\hline & \multicolumn{2}{|c|}{$1-5$ lat } & \multicolumn{2}{|c|}{ 5-10 lat } & \multicolumn{2}{|c|}{$10-15$ lat } & \multicolumn{2}{|c|}{ 15-20 lat } & \multicolumn{2}{|c|}{$>20$ lat } \\
\hline & $\mathrm{n}=3$ & $100 \%$ & $\mathrm{n}=4$ & $100 \%$ & $\mathrm{n}=7$ & $100 \%$ & $\mathrm{n}=12$ & $100 \%$ & $\mathrm{n}=24$ & $100 \%$ \\
\hline $\begin{array}{c}\text { Nie był } \\
\text { sprawdzany }\end{array}$ & 2 & $66,7 \%$ & 3 & $75 \%$ & 4 & $57,1 \%$ & 7 & $58,3 \%$ & 14 & $58,3 \%$ \\
\hline Raz na rok & 1 & $33,3 \%$ & 1 & $25 \%$ & 3 & $42,9 \%$ & 5 & $41,7 \%$ & 10 & $41,7 \%$ \\
\hline
\end{tabular}

Tabela 4. Kontrola poziomu przeciwciał anty-HBS wśród lekarzy

\begin{tabular}{|c|c|c|c|c|c|c|c|c|c|c|}
\hline \multirow{4}{*}{$\begin{array}{l}\text { Odpowiedzi } \\
\text { lekarzy }\end{array}$} & \multicolumn{10}{|c|}{ Jak często sprawdzany jest poziom przeciwciał anty-HBS? } \\
\hline & \multicolumn{10}{|c|}{ STAŻ PRACY ANKIETOWANYCH LEKARZY } \\
\hline & \multicolumn{2}{|c|}{$1-5$ lat } & \multicolumn{2}{|c|}{$5-10$ lat } & \multicolumn{2}{|c|}{$10-15$ lat } & \multicolumn{2}{|c|}{ 15-20 lat } & \multicolumn{2}{|c|}{$>20$ lat } \\
\hline & $\mathrm{n}=2$ & $100 \%$ & $\mathrm{n}=3$ & $100 \%$ & $\mathrm{n}=4$ & $100 \%$ & $\mathrm{n}=11$ & $100 \%$ & $\mathrm{n}=30$ & $100 \%$ \\
\hline $\begin{array}{c}\text { Nie był } \\
\text { sprawdzany }\end{array}$ & 1 & $50 \%$ & 2 & $66,7 \%$ & 2 & $50 \%$ & 7 & $63,6 \%$ & 23 & $76,6 \%$ \\
\hline Raz na rok & 1 & $50 \%$ & 1 & $33,3 \%$ & 2 & $50 \%$ & 4 & $36,4 \%$ & 7 & $23,4 \%$ \\
\hline
\end{tabular}

Bez względu na wykształcenie, pielęgniarki utrwalały wiedzę na temat ekspozycji zawodowej przez własną samodzielną edukację $(83,3 \%$ ze średnim wykształceniem, $83,3 \%$ z wyższym wykształceniem). Aktualizacja i kontrola znajomości procedur zdaniem pielęgniarek w dużej mierze utrwalała wiedzę na temat postępowania $\mathrm{w}$ przypadku ekspozycji zawodowej.

Jak wynika $z$ badań, utrwalanie wiedzy dotyczącej postępowania poekspozycyjnego przez lekarzy bez względu na staż pracy, to przede wszystkim samodzielne poszerzanie wiadomości (100\% ankietowanych w wieku 1-10 lat pracy).

Nie wszystkie pielęgniarki zgodnie stwierdziły, że w miejscu pracy odbywają się regularne szkolenia, zdecydowana większość pielęgniarek samodzielnie poszerza swoją wiedzę (100\% ankietowanych ze stażem pracy od 1-15 lat). Analiza statystyczna wykazała silnie dodatnią zależność $(\mathrm{r}=0,8)$ miedzy stażem pracy a regularnym odbywaniem szkoleń. Również nie wszyscy lekarze stwierdzili, że w miejscu pracy odbywają się regularne szkolenia (100\% tylko w przypadku lekarzy ze stażem pracy 1- 5 lat). Zdecydowana większość lekarzy bez względu na staż pracy samodzielnie poszerza swoją wiedzę. 
Pielęgniarki bez względu na wykształcenie miały wiedzę na temat możliwości zapobiegania zakażeniom HCV i HBS. Również lekarze bez względu na staż pracy znali możliwości uniknięcia zakażenia HCV i HBV.

\section{Dyskusja}

Ręce personelu medycznego stanowią najważniejszy wektor rozprzestrzeniania się zakażeń szpitalnych w placówkach zdrowia, dlatego pracownicy zakładów opieki zdrowotnej powinni w sposób szczególny zwracać uwagę na higienę skóry dłoni. Badania pokazują, że zdecydowana większość ankietowanych pielęgniarek i lekarzy myła ręce po każdym kontakcie z pacjentem. Niepokoi fakt, że personel medyczny z ponad 20-letnim stażem pracy nie przestrzegał w $100 \%$ zasad higieny skóry dłoni po wykonaniu iniekcji. Potwierdzenie wyników badań własnych można znaleźć w uzyskanych wynikach przez Bilskiego i Kosińskiego [20], według których we wszystkich czynnościach wykonywanych przez personel medyczny zauważa się zaniedbania i nieprzestrzeganie w $100 \%$ procedur higienicznych.

Bilski i Kosiński [20] zwracają również uwagę na brak stosowania rękawiczek przy czynnościach, podczas których personel medyczny jest do tego zobligowany. Przeprowadzone badania własne pokazują, że zdecydowana większość pielęgniarek i lekarzy stosowała rękawiczki w każdej czynności przy pacjencie. Pielęgniarki z wykształceniem licencjackim $(85,8 \%)$ i wyższym $(66,7 \%)$ częściej stosowały rękawiczki przy zmianie opatrunku niż pielęgniarki z wykształceniem średnim (tylko 53,4\%). Przeprowadzone badania pokazują, że tylko połowa ankietowanych pielęgniarek bez względu na wykształcenie zakładała rękawiczki przy pobieraniu krwi.

Badania własne pokazują, że również lekarze bagatelizują konieczność stosowania rękawiczek. Bez względu na staż pracy wszyscy lekarze stosowali rękawiczki przy zmianie opatrunku, jednak tylko 1/3 ankietowanych przy pobieraniu krwi zakładała rękawiczki. W badaniu Garus i Szatko [21] z lat 2006-2007 przeprowadzonym na grupie pielęgniarek, aż 72,1\% ankietowanych przyznała, że przestrzega procedur higienicznych w swojej pracy. Prawie 1/3 (27,9\%) odpowiedziała jednak, że czasem zdarza im się te procedury pomijać.

Praca personelu medycznego przy pacjencie związana jest z ciągłym narażeniem na zakażenia krwiopochodne. Najczęściej do ekspozycji zawodowej dochodzi poprzez zakłucie brudną igłą. Stein i Makarawo [22] w swoich badaniach z Birmingham wykazali, że 37\% personelu medycznego przynajmniej raz uległo zranieniu zużytą igłą (53\% lekarzy, 29\% pielęgniarek). Badania własne pokazują, że bez względu na staż pracy to u lekarzy częściej dochodziło do zakłucia igłą (aż $75 \%$ lekarzy ze stażem pracy od $10-15$ lat, $54,4 \%$ ze stażem pracy ponad 20 lat). Badane pielęgniarki w większości przyznały, że w ich pracy nie doszło do zakłucia się igłą, która miała kontakt z krwią. 
Badania własne pokazują, że 100\% ankietowanych pielęgniarek i lekarzy w przypadku wystąpienia ekspozycji poinformowałby przede wszystkim przełożonego, a następnie szefa dyżuru. Niepokojący jest fakt, że 9,1\% lekarzy ze stażem pracy 15-20 lat, odpowiedziało, że zgłosiłoby fakt zaistniałej ekspozycji przy okazji przełożonemu.

Najpowszechniejszym wśród personelu medycznego źródłem wiedzy na temat ekspozycji i postępowania poekspozycyjnego jest przede wszystkim samodzielne poszerzanie wiedzy. Zdecydowana większość pielęgniarek przyznała, że w miejscu pracy nie odbywają się regularnie szkolenia dla personelu. Tylko lekarze ze stażem pracy od 1 do 5 lat (100\%) przyznali, że w miejscu pracy odbywały się regularne szkolenia dla personelu, pozostali ankietowani zgodnie przyznali, że samodzielnie poszerzali wiedzę na temat ekspozycji na materiał zakaźny. Badania wskazują na potrzebę organizacji szkoleń dla personelu medycznego w zakresie ekspozycji zawodowej i postępowania poekspozycyjnego

Wiele środowisk medycznych w Polsce, pomimo ciągle zbyt małych nakładów finansowych, podejmuje trud uświadomienia zarówno decydentom, jak i społeczeństwu wagi problemu, jednak jak wskazują badania nadal jeszcze bardzo wiele pozostaje do zrobienia.

\section{Wnioski}

1. Personel medyczny znał procedury postępowania w przypadku zakłucia się niesterylnym narzędziem.

2. Zdecydowana większość personelu medycznego stosowała rękawiczki jako środek ochrony osobistej. Nie wszystkie pielęgniarki stosowały rękawiczki przy pobieraniu krwi czy przy zmianie opatrunku. Nie wszyscy lekarze stosowali rękawiczki przy pobieraniu krwi czy w czasie badania fizykalnego.

3. Zdecydowana większość personelu medycznego przestrzegała zasad mycia rąk podczas wykonywanych czynności. Jednak część ankietowanych przyznała, że po wykonaniu iniekcji nie zawsze myła ręce.

4. Personel medyczny wiedział, kogo w przypadku wystąpienia ekspozycji powiadomić.

5. Utrwalanie wiedzy dotyczącej postępowania poekspozycyjnego przez lekarzy i pielęgniarki bez względu na staż pracy to przede wszystkim samodzielne poszerzanie wiadomości. Szkolenia wewnątrzszpitalne zdaniem personelu medycznego odbywały się rzadko.

6. Personel medyczny bez względu na wykształcenie znał procedury zapobiegania zakażeniom HCV i HBV. 


\section{Bibliografia}

1. Halota W, Pawłowska M. Wirusowe zapalenia watroby typu C. Wyd Med Termedia, Poznań 2009.

2. Magdzik W, Naruszewicz-Lesiuk D, Zieliński A. Wakcynologia. $\alpha$-medica Press, Bydgoszcz 2007.

3. Magdzik W. (red.) Choroby zakaźne i pasożytnicze. Zapobieganie i zwalczanie. III wydanie „Vesalius” Uniwersyteckie Wydawnictwo Medyczne, Kraków 1993.

4. Juszczyk J. Wirusowe zapalenie watroby. Wydawnictwo Lekarskie PZWL, Warszawa 1999.

5. Juszczyk J. Hepatitis B. Roche Polska, Warszawa 1995.

6. Polański JA. Hepatologia-kompendium. Wyd. Medical Tribune, Warszawa 2004.

7. Damacewicz M, Szymankiewicz M, Kowalewski J, Karwacka M. Postępowanie w przypadku ekspozycji pracowników szpitala na HBV, HCV i HIV. Przegląd Epidemiologiczny. 2005; 59: 671-677.

8. Bandoła K, Seweryn M, Pokrzywa P. Ogniska zakażeń szpitalnych w województwie małopolskim w latach 2006-2010. Zakażenia. 2012; 4: 81-87.

9. Rymer W, Beniowski M, Mularska E. Profilaktyka poekspozycyjna po narażeniu na zakażenie HIV, HBV, HCV. [w:] Horban A, Podlasin R, Cholewińska G, Wiercińska-Drapało A [red.] Zasady opieki nad osobami zakażonymi HIV. Zalecenia Polskiego Towarzystwa Naukowego AIDS. Warszawa 2011; 397-405.

10. Centers for Disease Control and Prevention. Workbook for Designing, Implementing, and Evaluating a Sharps Injury Prevention Program. 2008.

11. Rybacki M, Piekarska A. [red.] Zapobieganie zakażeniom krwiopochodnym u personelu medycznego - poradnik dla służb BHP, PIS i PIP, pracodawców i pracowników. Oficyna Wydawnicza Instytutu Medycyny Pracy im. prof. J. Nofera, Łódź 2012.

12. Magdzik W. Epidemiologia wirusowych zapaleń watroby typu $B$ i $C$ w Polsce, z uwzględnieniem dzieci. Hepatologia Polska 1997; (Supl. 1) 4,5.

13. Hryniewicz HJ. Profilaktyka poekspozycyjna zakażeń HBV, HCV i HIV u personelu medycznego. Medycyna po Dyplomie. 2006; 15(2): 35-38.

14. Szczypta A. Ekspozycja zawodowa pracowników ochrony zdrowia na czynniki biologiczne - działania profilaktyczne. Seminarium „Rękawice medyczne ogniwo w procesie przeciwdziałania zakażeniom”. Rytro 2007.

15. Gańczak M. Ekspozycja zawodowa - ocena skali problemu i metod prewencji. Ogólnopolski Kongres Ekspozycji Zawodowej Podsumowanie, Artykuły Rady Ekspertów Kongresu, Pałac Kultury i Nauki w Warszawie, 19.04.2012.

16. Chłosta P, Gąsiorowski J, Antoniewicz AA, Szcześniak C, Krys B. Objawy ze strony układu moczowo-plciowego w przebiegu zakażeń HIV i AIDS. Najważniejsze zasady Profilaktyki poekspozycyjnej u personelu stużby zdrowia. Wyd. Borgis-Nowa Medycyna. 2000; 5.

17. Wytyczne WHO dotyczące higieny rąk w opiece zdrowotnej - podsumowanie. Pierwsza Światowa Inicjatywa na rzecz Bezpieczeństwa Pacjenta „Higiena rąk to bezpieczna opieka". WHO, 2009.

18. Różkiewicz D. Ręce personelu jako potencjalne źródło zakażeń szpitalnych. Zakażenia. 2011; 5; 6-12. 
19. Przondo Mordarska A, Bartoszewicz M. V Akademia Pielegniarstwa. Konferencja naukowo szkoleniowa. Postępowanie diagnostyczne szpitala zapobiegające zakażeniom szpitalnym, Wrocław 2012.

20. Bilski B, Kosiński B. Analiza wybranych zachowań w zakresie higieny rak $w$ wybranej populacji personelu pielęgniarskiego. Med. Pracy 2007, 58 (4): 291-297.

21. Garus-Pakowska A, Szatko F. Wiedza pielęgniarek na temat zakażeń zwiazanych z opieka zdrowotna. Probl Hig Epidemiol. 2009, 90 (1): 62-66.

22. Stein A, Makarawo T, Ahmad M. A survey of doctors' and nurses' knowledge, attitudes and compliance with infection control guidelines in Birmingham teaching hospitals. J Hosp Infect. 2003; 54: 68-73.

\title{
Evaluation of medical staff knowledge about the incidence of hepatitis $B$ and $C$
}

\begin{abstract}
Introduction: Nosocomial infections largely concern health professionals. The increased range of medical services and surgical procedures leads to an increased incidence of hepatitis $\mathrm{B}(\mathrm{HBV})$ and $\mathrm{C}(\mathrm{HCV})$ infections among this professional group. The main cause of nosocomial infections among people working in the healthcare sector is occupational diseases resulting from exposure to biological agents in the line of official duties. According to WHO, every year the world's 3 million health workers are exposed to percutaneous contact with blood-borne pathogens. The aim of the study was to assess medical staff knowledge concerning the incidence of acute hepatitis $\mathrm{B}$ and $\mathrm{C}$.

Results and conclusion: Analysis of medical staff knowledge on the incidence of hepatitis $\mathrm{B}$ and $\mathrm{C}$ shows that medical staff do know how they should behave when they come into contact with infectious material in the healthcare institutions.
\end{abstract}

Key words: infection post-exposure, puncture, nurses, doctors 